\title{
Immigration, Attitudes and the Rise of the Political Right: The Role of Cultural and Economic Concerns over Immigration
}

\author{
Lewis S. Davis \\ Sumit S. Deole
}

CESIFO WORKING PAPER NO. 5680

CATEgory 2: Public CHOICE

DECEMBER 2015
An electronic version of the paper may be downloaded
- from the SSRN website: Www.SSRN.com
- from the RePEc website: $\quad$ www.RePEc.org
- from the CESifo website: www.CESifo-group.org/wp




\title{
Immigration, Attitudes and the Rise of the Political Right: The Role of Cultural and Economic Concerns over Immigration
}

\begin{abstract}
With the rise of the far-right parties in the European parliamentary elections, concerns over immigration and national identity have again come into the limelight. In this paper, we document the empirical relationships between immigration, native concerns over the economic and cultural impact of immigration, and the rise of rightwing political parties in Europe. Empirical analysis first establishes the critical and distinct roles played by economic and cultural concerns over immigration in determining citizen's rightward ideology and voting for rightwing parties. Second, we investigate the determinants of economic and cultural concerns over immigration, finding strong and consistent evidence for the salience hypothesis, which suggests that immigrant share of a country's population shapes citizen concerns over immigration. Thereafter, we document the roles of macro-level economic and cultural channels in determining the strength of salience effects. Finally, we investigate how the characteristics of the immigrant population affect native concerns over immigration.
\end{abstract}

JEL-Codes: D720, F220, Z130.

Keywords: group threat hypothesis, attitudes toward immigrants, cultural threat, public opinion, immigration policy, and right-wing politics.

Lewis S. Davis

Department of Economics

Union College

USA - Schenectady NY 12308

davisl@union.edu
Sumit S. Deole*

Department of Economics

University of Halle-Wittenberg

Halle (Saale) / Germany

sumit.deole@wiwi.uni-halle.de

*corresponding author

December 12, 2015

We would like to thank Hakon Albers, George Bizer, Asmae El Gallaa, Gregor von Schweinitz, and the attendees of the research colloquium at the Martin-Luther-Universität for useful comments. 
"The progressive Islamisation of our country and the increase in political-religious demands are calling into question the survival of our civilisation." Marine Le Pen, President of the French National Front Party (FN), The Daily Telegraph, Dec. 26, 2010.

"Our Judeo-Christian culture is far superior to the Islamic one." Geert Wilders, Founder and leader of the Dutch Party for Freedom, Speech in Garland, Texas, May 3, 2015.

\section{INTRODUCTION}

As the quotes above indicate, concerns over the cultural impact of immigration on European society play a central role in the rhetoric of contemporary rightwing politicians, and indeed, anti-immigrant sentiment has contributed to the rise of rightwing political parties across Europe (The Economist, 2014). ${ }^{1}$ Table 1 presents the share of the vote received by rightwing political parties in recent elections for selected European countries. A long tradition in economics, originating with Marx and carried forward by the Chicago School, would tend to discount the explicitly stated concerns over culture and national identity expressed in these quotes, viewing them as manifestations of more fundamental conflicts over resources and economic opportunity. In contrast, the tradition in sociology, originating with Max Weber, holds that cultural factors may play an independent causal role in economic and political life. ${ }^{2}$ With respect to the rise of the political right in contemporary Europe, the question becomes whether it is most directly linked to economic or cultural concerns, and to what degree these concerns are rooted to deeper economic and cultural factors?

These are questions on which the existing literature sheds little light. Chandler and Tsai (2001), Sides and Citrin (2007), Facchini and Mayda (2008), and Jolly and DiGiusto (2014) find that opposition to immigration is associated with conservative or rightwing ideologies, and Billet and De Witte (1995) and Lubbers et al. (2002) show as well that opposition to immigration is associated with the propensity to vote for rightwing political parties. However, these papers employ general or composite measures of attitudes toward immigration and, thus, fail to specifically address the role of cultural concerns over immigration or to distinguish between the

\footnotetext{
${ }^{1}$ Please follow the link: http://www.economist.com/news/briefing/21592666-parties-nationalist-rightare-changing-terms-european-political-debate-does

${ }^{2}$ See Guiso et al. (2006) for further discussion of this point.
} 
roles of cultural and economic concerns over immigration in support for rightwing political parties and ideologies. Furthermore, none of these papers explicitly addressed the deeper foundations of concern over immigration.

We address these issues directly by exploiting largely ignored variables in the European Social Survey (2002-2010) that ask respondents directly about their opinion on the impact of immigration on the economy and on the national culture. As suggested by the quotes above, these dimensions of concern have different implications for political attitudes and behavior. In particular, we find that cultural concerns over immigration play a larger role than economic concerns in determining an individual's (self-reported) position on a left-right ideological continuum and the probability that an individual voted for a rightwing party. Distinguishing between economic and cultural concerns over immigration is also important because different types of concern may best be addressed through different policy interventions. For example, economic concerns might be addressed through changes in labor market or welfare policies, while cultural concerns might involve language acquisition and other assimilation-oriented policies.

We also extensively explore and distinguish between the determinants of economic and cultural concerns over immigration and, in doing so, provide a more nuanced understanding of attitude formation. A number of scholars have focused on the relative merits of different theoretical approaches to understanding the formation of native attitudes toward immigration, essentially running horse races for the different lines of theory. In contrast, we find support for a number of theories of native attitude formation, with different theories best explaining the formation of economic and cultural concerns.

The dominant school of thought on native responses to immigration is group threat theory, which suggests that hostility to immigration is a response to perceived threat of immigration to the interests or social position of the dominant group (Blumer, 1958; Blalock, 1967). ${ }^{3}$ These perceived threats are greatest in challenging economic times, tend to be increasing in the size of the immigrant population, and may reflect threats to the economic welfare, social status, or cultural hegemony of the dominant group.

The economic underpinnings of this perspective dovetail well with a large body of work that investigates the role of economic self-interest related to labor market

\footnotetext{
${ }^{3}$ See Vallas et al. (2009) for a discussion of theoretical approaches to understanding the formation of attitudes toward immigrants.
} 
competition and the provision of public goods in the response to immigration (Dustmann and Preston, 2006, 2007; Facchini and Mayda, 2009; Senik et al., 2009; Helbling and Kriesi, 2014). The labor market competition channel maintains that natives perceive immigration negatively fearing that they will lose their jobs to similarly skilled immigrants. Whereas, welfare concerns' theory points at the fear among natives that immigrants free ride on the welfare safety net of the host countries. Broadly speaking, both channels propose that attitudes toward immigrants will depend on the economic characteristics of individuals, countries and the immigrant population.

Native attitudes toward immigration may also reflect fears regarding the loss of socio-economic status. In contrast to the labor market and welfare channels, which are driven by the impact of immigration on real income levels, status concerns involve falling relative income levels. For example, a low-skill native facing high skill immigration may see her real income rise (due to skill complementarities, for example), while her relative income falls, reducing her status. While the existing literature has not given much prominence to the role of socio-economic status in native attitudes toward immigration, a large empirical literature highlights the role of status in subjective wellbeing (Clark et al., 2008).

Finally, the cultural perspectives hypothesis "attributes independent causal power to normative orientations" of the native population, reflecting native attachment to regional traditions, collective identities and cultural values (Vallas et al., 2009, p. 202). Normative concerns may reflect nationalism (Quillian, 1995; Mayda, 2006; Sides and Citrin, 2007), racism or ethnocentrism (Quillian, 1995; Citrin et al., 1997; Dustmann and Preston, 2007), parochialism (Schneider, 2008; Vallas et al., 2009), language (Chandler and Tsai, 2001), religious sectarianism (Facchini et al., 2013), or concerns over immigrant work ethic (Helbling \& Kriesi, 2014). The cultural perspectives approach is sometimes presented as an independent theoretical construct and sometimes as a strand of the group threat theory.

We structure our empirical investigation around two propositions, the salience hypothesis and the alignment hypothesis. The salience hypothesis, which originates with Blalock (1967), is the conjecture that opposition to an out-group is increasing in group's share of the population and plays a central role in the literature on attitudes toward immigration. e.g. Quillian (1995), Dustmann and Preston (2001), Semyonov et al. (2008), and Ceobanu (2010). As noted below, we are able to significantly advance the state of the literature regarding the role of immigrant share in influencing attitudes toward immigration. 
The alignment hypothesis is of our own invention and concerns how cultural and economic factors play into the formation of concerns over the cultural and economic impact of immigration. In particular, the alignment hypothesis holds that the economic characteristics of individuals, countries and immigrants are more important in determining economic than cultural concerns over immigration, while cultural characteristics play a greater role in determining cultural than economic concerns. Exploring the alignment hypothesis sheds light on the more fundamental economic and cultural determinants of the economic and cultural concerns of European natives and, thus, on the debate between Marx and Weber.

A particular strength of the analysis presented here derives from our use of an international pseudo-panel, which allows us to identify the impact of marginal changes in the immigrant population share while controlling for unobserved country and period effects. In contrast, studies employing cross-sectional data from a single point in time, such as Quillian (1995), Espenshade et al. (1996), Evans and Need (2002), Sides and Citrin (2007), Semyonov et al. (2008), Strabac and Listhaug (2008), and Ceobanu (2010), cannot address the how attitudes toward immigrants respond to changes in share or composition of the immigrant population, nor can they effectively control for omitted country-level variables that may be correlated with macroeconomic indicators, such as unemployment or the immigrant population share. Similarly, studies that employ national panel data, such as Dustmann and Preston (2001), Semyonov et al. (2004), Wilkes and Corrigall-Brown (2011), and Jolly and DiGiusto (2014), are unable to investigate the determinants of international differences in the sensitivity of attitudes toward immigrants, including various dimensions of national culture.

Our key findings are as follows. First, and most fundamentally, we document statistically significant and economically substantial differences between economic and cultural concerns over immigration. Economic and cultural concerns over immigration differ with respect to their determinants as well as their implications for political values and behavior. This finding supports our efforts to distinguish between these dimensions of concern and suggests that this distinction may be important to future research in this area.

Second, we find consistent support for the salience hypothesis: immigrant population share is significant, either alone or interacted with other variables, in every specification we examine. This is an important finding because the existing evidence on the salience hypothesis has been decidedly mixed. For example, Quillian (1995), Dustmann and Preston (2001), Semyonov et al. (2008), and Ceobanu (2010) observe a positive association between the relative size of the foreign population 
and anti-immigrants attitudes, whereas, Evans and Need (2002), Semyonov et al. (2004), Sides and Citrin (2007), Strabac and Listhaug (2008), and Jolly and DiGiusto (2014) find no such relationship. ${ }^{4}$ The use of panel estimation techniques in this paper for cross-national comparisons puts this result on firmer econometric footing by reducing concerns over the impact of omitted country-level variables.

We also refine the salience hypothesis in two ways. First, we find that the immigrant population share plays a substantially larger role in the formation of economic than cultural concerns over immigration. And, second, we find that salience effects are mediated by macroeconomic conditions and dimensions of national culture. These results reflect substantial differences in the response to immigration across countries and time, and may go some distance toward explaining disparate findings regarding the salience effect in the existing literature. The roles of macroeconomic conditions and national culture in salience effects also suggest limits to our ability to extrapolate the findings of country-level analyses to other settings.

Third, we document an important fault-line in support for the alignment hypothesis. The evidence on individual-level characteristics supports the alignment hypothesis: an individual's economic characteristics matter more for their economic than their cultural characteristics, and vice versa. However, the alignment hypothesis does not hold for country-level variables. Macroeconomic conditions appear to play a roughly equal role in economic and cultural concerns over immigration, while measures of national culture matter only for economic concerns over immigration. Finally, the economic characteristics of the immigrant population matter for both economic and cultural concerns over immigration. In this case, economic concerns appear to reflect labor market and welfare channels, cultural concerns appear to reflect fears over the loss of socio-economic status.

The remainder of our paper is organized as follows. Section 2 introduces the data. Section 3 presents results on 1) immigration concerns and political variables and 2) examines the individual-level determinants of concerns over immigration. Section 4 considers the role of macroeconomic conditions, national culture and the characteristics of the immigrant population. Section 5 concludes.

\footnotetext{
${ }^{4}$ Unlike other studies listed here, Jolly \& DiGiusto (2014) finds a negative relationship between immigrant concentration and xenophobia for France.
} 


\section{DATA}

In this section, we further provide more information about the data used for this study. Our primary data source is the first five waves of the European Social Survey (ESS) consisting of observations from 22 European countries: Austria, Belgium, Switzerland, the Czech Republic, Germany, Denmark, Estonia, Spain, Finland, France, Great Britain, Greece, Hungary, Ireland, Luxembourg, the Netherlands, Norway, Poland, Portugal, Sweden, Slovenia, and the Slovak Republic. ESS is a biannually conducted survey that started in the year 2002. Its special focus on migration and minorities adds value to our choice of the survey. We limit our analysis to the first five rounds, e.g. through 2010, due to the availability of data on immigrant population share. Given our explicit concern with the role of immigration concerns in political outcomes, we also restrict the analysis to respondents who are citizens of the country in which they are surveyed.

\subsection{Individual-Level Variables}

Individual level variables are taken from the ESS survey responses and include economic and cultural concerns over immigration, political ideology, voting behavior, and a variety of demographic, economic and cultural characteristics that may influence attitudes toward immigration. Summary statistics for these variables are presented in Table 2 .

The main dependent variables in our analysis consist of two variables that record a respondent's concerns over the economic and cultural impact of immigration on their country. The question recording a citizen's economic concerns towards immigration asks: "Would you say it is generally bad or good for [country's] economy that people come to live here from other countries?" The individual response to this question ranges in the scale from $0-10$, where 0 indicates that the respondent believes immigration is bad for the economy, and 10 indicates that respondent perceives that immigration is good for the economy. Our measure of cultural concerns over immigration is derived from a similar question, which asks: "Would you say that [country's] cultural life is generally undermined or enriched by people coming to live here from other countries?" The answer 0 to this question signifies that the respondent believes that immigration undermines the cultural life, and the response 10 suggests that the respondent perceives that immigration enriches the cultural life of her country.

We manipulate the raw data on concern over immigration in two ways. First, we reverse the order of the responses so that higher values are associated with greater 
concern over the impact of immigrants. Second, we normalize these variables using the standardized coefficients technique. The resulting variables have zero means and standard deviations of one. Normalization facilitates our investigation of the alignment hypothesis, which requires that we compare results for regressions employing the two measures of concern as dependent variables.

We rely on two variables to document the relationship between concerns over immigration and a respondent's politics. The first variable records a respondent's answer to the following question: "In politics people sometimes talk of 'left' and 'right'. Using this card, where would you place yourself on this scale, where 0 means the left and 10 means the right?" We transform this variable using the standardized coefficient technique. We interpret increases in this variable as a rightward shift in an individual's underlying political views.

To measure political behavior, we rely on two measures. First, we construct an measure of individual voting behavior based on an ESS variable recording the party an individual voted on in the most recent election. The results are then matched with a list of right-wing parties to create the variable "rightwing", which takes the value of one if an individual voted for a right-wing party and zero otherwise. Table 12 lists right-wing European political parties and is constructed using information from Ivarsflaten (2006), Rydgren (2008), and Mudde (2012, 2013).

In investigating the individual-level determinants of concerns over immigration, we employ a variety of variables that reflect an individual's demographic, economic and cultural characteristics. Demographic variables include an individual's age, gender, marital status, and a dummy variable for whether there are children living at home. Economic variables include measures of an individual's income, education level and employment status. Cultural variables include an individual's religious affiliation, immigration status of their parents, and a measure of religiosity, as indicated by attendance at religious services. This categorization is clearly imperfect, as many variables could count in multiple categories, e.g. education arguably influences an individual's cultural identity as well as her economic situation, and is based in part on our subjective judgment and partly on previous work.

\subsection{Country-Level Variables}

Key country-level variables include the immigrant population share, the national unemployment rate and real per capita income, two measures of national culture, and economic and religious characteristics of the immigrant population. Summary statistics for these variables are presented in Table 3. 
The immigrant share of the population is used to test the salience hypothesis, which holds that the perceived threat of an out-group rises with its share of the population and is most closely associated with the group threat hypothesis Blalock (1967). Data on immigrant population share comes from OECD's migration statistics. ${ }^{5}$

Group threat theory suggests that native hostility to immigrants will be a function of economic conditions in a given area. While most analyses of group threat theory focus on the unemployment rate, Friedman (2005) argues that economic growth alters people moral sentiments, making them less concerned with horizontal social comparisons and more accepting of policies that benefit excluded or marginalized groups. ${ }^{6}$ In light of this argument, we use two measures of macroeconomic conditions, the unemployment rate and real per capita income. These variables are from OECD labor market statistics?.

We test cultural perspectives theory using two dimensions of national culture that reflect a country's religious diversity and its position on the individualismcollectivism continuum. Our motivation for considering religious diversity comes from contact theory, which holds that hostility to immigration stems for social and institutional barriers between immigrant and native populations (Vallas et al., 2009). A broad reading of contact theory suggests that the experience of living in a religiously diverse society would tend to make natives less concerned with other forms of social diversity, including those associated with immigration. Our measure of religious diversity is from McCleary and Barro (2006) and equals one minus the sum of the squares of the population shares belonging to ten religious traditions. Intuitively, this measure reflects the probability that any two randomly selected individuals will belong to the same religious or philosophical tradition. To avoid issues of reverse causation, we measure religious diversity in 1970 .

Second, we use a measure of individualism, which is widely regarded as the most important component of a country's cultural make-up (Gorodnichenko and Roland, 2011; Hofstede, 2001). Individualism and collectivism reflect the importance of social relationships in an individual's identity (Gorodnichenko and Roland, 2011), and individuals who are less attached to national, ethnic and religious identities may be less sensitive to the perceived threats to these group identities posed by

\footnotetext{
${ }^{5}$ The data for the immigrant population share in European countries is collected from OECD (2014) International Migration Outlook.

${ }^{6}$ See Davis \& Knauss (2013)for a discussion and empirical test of Friedman's hypothesis.

${ }^{7}$ The data for the harmonized unemployment rate can be found on the following link: https://data.oecd.org/unemp/harmonised-unemployment-rate-hur.htm\#indicator-chart
} 
immigration. Furthermore, individualism is strongly associated with having a general rather than limited morality and, thus, with more moderate distinctions between social insiders and outsider Alesina and Giuliano, "Culture and Institutions.". Our measure of individualism is from Hofstede $(1985,2001)$ and is the most commonly used measure in the social sciences.

Finally, we consider a number of economic and cultural characteristics of the immigrant population. To construct these variables, we combine information from the OECD and ESS data sets. Although ESS survey is a rich source of information on the characteristics of individual immigrants, it may lack the representativeness for the actual migrant share. Hence, as an initial correction, we rescale the ESS data so that the share of the foreign born (calculated from the ESS) matches the OECD data on migrant share. ${ }^{8}$ The scale is simply the ratio of OECD estimate of share of foreign born to that from the ESS for each country and for every year. Then we multiply various migrant share types obtained from the ESS with this scale and obtain the scaled immigrant shares categorized by employment status, education level, and religious affiliation. We use this categorization to study whether certain characteristics of immigrant population are associated with natives' concerns over immigration. Following the alignment hypothesis, we expect to find that economic characterization of immigrant population (employment status and education level) should associate with natives' economic concerns over immigration, whereas, religious characterization should relate to cultural concerns of the natives over immigration.

\section{RESULTS AND DISCUSSION}

\subsection{Concerns over Immigration, Political Ideology and Voting Behavior}

We begin by considering how economic and cultural concerns over immigration are related to political ideology and voting behavior. While voting behavior is attractive measure of an individual politics, due to its central role in electoral politics and policy formation, there are two reasons to consider political ideology as well. First, an exclusive focus on voting behavior may miss important channels through which attitudes toward immigration influence policy, such as political contributions and lobbying (Facchini and Mayda, 2008; Facchini et al., 2011). Second, our measure of voting behavior, a dummy variable for whether an individual voted for a rightwing

\footnotetext{
${ }^{8}$ The correlation between these measures of immigrant share is very high: 0.922 . However, it is important to note that our measures of immigrant subcategories will be subject to measurement error if immigrant subgroups have different response rates.
} 
party, is potentially subject to substantial systematic measurement error. In particular, social desirability bias may lead to a higher rate of non-response among rightwing voters when asked to identify the party for which they voted. In keeping with this concern, we note that a significant portion $(23 \%)$ of our sample of European voters failed to respond to the question identifying their party.

Our findings are presented in Table 4. In the first three columns of Table 4 the dependent variable is an individual's self-reported position on a left-right political spectrum. An increase in this variable is associated with a rightward shift in political ideology. Our primary independent variables are an individual's economic and cultural concerns over immigration. In addition, we control for the respondent's demographic, economic and cultural characteristics listed in Table 2 as well as for country and period fixed effects.

As seen in the first two columns, both economic and cultural concerns over immigration are associated with ideological positions on the political right. The coefficients on these variables are highly significant and relatively similar in magnitude. When entered jointly, however, we see that cultural concerns over immigration play a much greater role in an individual's rightward political selfidentification. A one-standard deviation increase in cultural concern is associated with an increase in rightward ideology by 14 percent of a standard deviation, while a one-standard deviation increase in economic concerns is associated with an increase in rightward ideology by $2.7 \%$ of a standard deviation, a difference in magnitude of roughly five fold.

A similar pattern of influence emerges when we examine voting behavior, though the difference in magnitude is not as extreme. Our dependent variable for these regressions is a dummy variable for whether the respondent voted for a right-wing party. We estimate columns four through six using a probit estimator and employ the same set of control variables used in columns one through three. Our results indicate that economic and cultural concerns over immigration play a role in voting behavior, with both forms of concerns over immigration associated with a greater propensity to vote for a rightwing party. Note also that cultural concerns appear to play a greater role than economic concerns in determining voting behavior. Oneunit increases in economic and cultural concerns is associated with an increased in the probability of voting for a rightwing party by 19 percent and 25 percent, respectively, indicating that the influence of cultural concerns is on voting behavior is roughly $30 \%$ larger than that of economic concerns. 
In conclusion, both economic and cultural concerns over immigration appear to play a role in political variables, affecting an individual's political ideology to the right and making it more likely that he or she will vote for a rightwing party. In addition, cultural concerns over immigration play a larger role in determining political ideology and voting behavior than do economic concerns over immigration. These results suggest it is important to distinguish between economic and cultural concerns over immigration and their determinants, which is the task to which we now turn.

\subsection{Individual Characteristics and Concerns over Immigration}

In this section, we examine the relationship between the immigrant population share, individual characteristics and concerns over immigration. As noted in the introduction, our investigation is guided by two hypotheses. The first is the salience hypothesis, which holds that concerns over immigration should be increasing in the immigrant population share. The second, the alignment hypothesis, holds that cultural variables, such as an individual's religious affiliation, should play a greater role in determining cultural concerns over immigration, while economic variables, such as an individual's employment status, should play a greater role in determining economic concerns over immigration.

Our baseline empirical model is as follows:

$$
A_{\text {ict }}=\beta_{1} S_{c t}+\beta_{2} X_{\tilde{i}}+\beta_{3} E_{i}+\beta_{4} C_{i}+\gamma_{c}+\gamma_{t}+\mu_{\text {ict }}
$$

In this specification, the dependent variable $\mathrm{A}_{\mathrm{i}}$ measures individual i's self-reported attitude cultural concerns towards immigration; $\mathrm{S}_{\mathrm{c}, \mathrm{t}}$ is the migrant share (foreign born) in the country $\mathrm{c}$ at time $\mathrm{t} ; \mathrm{X}_{\mathrm{i}}, \mathrm{E}_{\mathrm{i}}$ and $\mathrm{C}_{\mathrm{i}}$ are vectors of i's demographic, economic and cultural characteristics; and $\gamma_{\mathrm{c}}$ and $\gamma_{\mathrm{t}}$ are the country and time specific dummies; and $\mu_{i}$ is the error term. The inclusion of country fixed effects allows us to control for unobserved, time-invariant variables that might be correlated with key variables of interest, such as the immigrant share. Similarly, the inclusion of period fixed effects allows us to control for Europe-wide shocks to

concerns over immigrants, such as may have occurred following high profile terrorist events. Given the multinomial nature of the dependent variables used in this study, we have double-checked our results using ordered logit regression 
method. The main results are robust to the choice of estimation methodology. We present results for weighted OLS regressions primarily for ease of interpretation. ${ }^{9}$

Table 5 presents the baseline regressions following the estimation strategy shown in equation (1). Columns (1) and (2) provide strong support for the salience hypotheses. The immigrant population share is a statistically significant determinant of both measures of concern over the impact of immigration. We note also that economic concerns are 2.74 times as sensitive to the immigrant share as are cultural concerns. Because we are controlling for country fixed effects, these coefficients reflect the association of changes in the share of the immigrant population with changes in immigration concerns. Moreover, these effects are economically large. For example, a 1.34\% increase in the share of the foreign born has roughly the same impact on economic concerns over immigration has having a native, rather than immigrant, father. Similarly, having a native father has the same impact on an individual's cultural concerns over immigration as a $3.66 \%$ rise in the foreign born share.

Note that since the immigrant share of a country's population is endogenous, the coefficients in Table 5 should not be interpreted as causal effects. The econometrically appropriate way to address the endogeneity of immigration is through the use of instrumental variables. However, we were unable to identify appropriate instruments. For example, an obvious source of exogenous variation in immigration flows is refugees. However, as suggested by Zimmermann et al. (2000) and O'Rourke and Sinnott (2006), the native response to refugees may differ from that to other immigrants ${ }^{10}$. That said, the available evidence suggests that hostility to immigration likely reduces immigration flows, either by influencing immigration policy (Facchini and Mayda, 2008; Facchini et al., 2011) or by making a country's social environment less hospitable to immigrants (Knabe et al., 2013). This suggests that the most important sources of endogeneity bias are negative and, as a result, the coefficient on the immigrant population share likely reflects a lower bound on the actual causal effect. Moreover, the magnitude of any bias due to reverse causation is likely to be very small (Olivier and Wong, 2003).

\footnotetext{
${ }^{9}$ We use both the design weight (DWEIGHT) and the population weight (PWEIGHT) for our study. For more information, please see "Weighting European Social Survey Data": http://www.europeansocialsurvey.org/docs/methodology/ESS weighting data.pdf. The standard errors are clustered on country level for all the regressions.

${ }^{10}$ Halla et al. (2012) use past immigrants' settlement patterns as an instrumental variable to address the issue of endogeneity in their analysis of the impact of immigrant share on the vote share of FPO in Austria. However, we consider that these historical patterns are not entirely exogenous to our modeling strategy and hence, are not appropriate instruments
} 
Next, we consider the alignment hypothesis. To help in interpreting our results in terms of the alignment hypothesis, we run a third regression, with results presented in column 3 , in which the dependent variable is the difference between an individual's economic and cultural concern over immigration. A significant coefficient in this column indicates that a given regressor plays a significantly different role in determining economic and cultural concerns, and thus potentially fits the alignment hypothesis. For example, we see that being married affects economic and cultural concerns differently, while living in an urban area does not.

The results in Table 5 largely support the alignment hypothesis. The bottom two rows of the table report F-statistics for the vectors of individual economic and cultural characteristics. These results suggest that the vector of economic characteristics, which includes income, education and employment status, is more important for economic than cultural concerns over immigration: $\frac{F_{E}^{B C}}{F_{E}^{C C C}}=\frac{28.53}{19.64}=1.4526$. Similarly, the vector of cultural characteristics, reflecting an individual's religiosity and ethnic and religious identity, is more important for cultural than economic concerns: $\frac{F_{C}^{C C}}{F_{C} E C}=\frac{137.5}{88.28}=1.5575$. These findings indicate that, collectively, an individual's economic characteristics matter more for her economic than cultural concerns over immigration and her cultural characteristics matter more for her cultural than economic concerns.

Turning next to individual regressors, we see that most of the results in Table 5 support the alignment hypothesis as well. For example, two of the variables related to employment status are significant determinants of an individual's economic concerns, while none are significant determinants of cultural concerns. Among the economic characteristics, exceptions to the alignment hypothesis are household income and education, which play a similar role in determining both types of concern. The last result is consistent with the idea that education is not exclusively an economic variable, but also plays an important role in shaping an individual's values and beliefs, e.g. Chandler and Tsai (2001), Hainmueller and Hiscox (2007), and Gang et al. (2013).

Most of the cultural variables fit the alignment hypothesis as well. Turning to column 3, we see that four of the religious affiliation variables, reflecting an individual's identity as Catholic, Protestant, Jewish and adhering to an Eastern religion, have a statistically significantly differential effect on the two dimensions of concern over immigration, and in each case the effect is larger on cultural than economic concerns over immigration. In contrast, religiosity reduces both forms of 
concern by a similar amount, while belonging to an ethnic minority is not significant in either regression. ${ }^{11}$

Table 6 presents a number of robustness checks on our results. In doing so we concentrate attention on the salience hypothesis and, thus, on the role of the immigrant population share. While we continue to control for the individual level characteristics used in Table 5, we do not report or discuss these results. In our initial robustness test, we rerun our baseline specification augmented to include a country-specific time trend. As indicated in columns 1 and 2, our results are largely robust to this change of specification. The coefficients on immigrant share are positive, significant and very similar in magnitude to those reported in Table 5. Next, we examine the effect of restricting the sample the countries of continental Europe and to EU member countries. As seen in columns 3-4 of Table 6, the immigrant population share continues to be strongly related to concerns over the economic and cultural impact of immigration.

Finally, we investigate specifications in which the relationship between migrant share and concerns among citizens towards immigration is non-linear. In the first specification, we consider a quadratic relationship between the immigrant population share and native concerns. As seen in columns 5 and 6, in both regressions the pattern of coefficient signs indicate a concave relationship between the immigrant share and economic and cultural concerns over immigration, though the coefficients on the squared term are not statistically significant.

In conclusion, we find substantial support for the salience and alignment hypotheses. Regarding the salience hypothesis, both economic and cultural concerns are increasing in the immigrant population share. Economic concerns also appear to be significantly more sensitive to changes in immigration than are cultural concerns. We also find strong support for the alignment hypothesis: both individually and collectively, cultural variables play a larger role in determining cultural than economic concerns over immigration, and economic variables play a larger role in determining economic than cultural concerns. Next, we turn our attention to the role of macroeconomic and national-cultural characteristics in influencing economic and cultural concerns over immigration. As we shall see below, the alignment hypothesis will no hold as consistently in these cases.

11 This result is in line with the existing research on religiosity and social tolerance, e.g. Guiso et al. (2003) and Facchini \& Mayda (2009). 


\section{IS THE RESPONSE TO IMMIGRATION UNIFORM ACROSS COUNTRIES?}

One of the key results of the previous section is support for the salience hypothesis, the view that concerns over immigration are increasing in the immigrant share of the population. A potential criticism of this finding is that the specifications used restrict the response to immigration to be uniform across countries. Put differently, our results may be thought of as reflecting this relationship in a hypothetical average country. In this section, we broaden the analysis to consider systematic differences in the response to immigration across countries. More specifically, we investigate how the response to immigration varies depending on the economic and cultural characteristics of the country and of the immigrant population.

\section{Group Threat Theory}

We begin by considering several variations on group threat theory, which suggests that native hostility to immigrants will be a function of economic conditions and of relative size of the minority group. In doing so, we consider three potential economic threats. We follow the existing literature by focusing on labor market competition and immigrant consumption of public goods and services (Dustmann and Preston 2006, 2007; Helbling and Kriesi 2014), and we extend the literature by considering the role of economic status as a perceived threat.

We examine these hypotheses using macroeconomic indicators and characteristics of the immigrant population. The macroeconomic indicators we employ are the unemployment rate and (the log of) per capita income. Higher rates of unemployment may increase anxiety over immigration by increasing the perceived competition between native and immigrant job seekers and by increasing the share of the immigrant population requiring public assistance. Per capita income may affect concerns over immigration by reducing the perceived burden of immigrant consumption of public services. More generally, economic growth may make people less concerned with horizontal social comparisons and, thus, more accepting of policies that benefit excluded or marginalized groups, as argued by Friedman (2005).

Our results are presented in Table 7 . We begin by adding the national unemployment rate to the baseline specifications used in Table 5. Columns one and two show that unemployment increases the level of economic concern over immigration, while leaving cultural concerns over immigration unchanged, a result that is consistent with the alignment hypothesis. The association of unemployment 
with economic concerns over immigration is also economically large. ${ }^{12}$ The point estimates indicate that a one-percent increase in unemployment is roughly 80 percent of the effect of a one percent increase in the share of the immigrant population.

In columns three and four, we include an interaction term to test whether the unemployment rate affects the sensitivity of concerns over immigration to the immigrant population share. Our results, a positive and significant coefficient on the interaction terms, suggest that it does. Point estimates indicate that unemployment increases economic concerns over immigration for countries in which the immigrant share of the population is greater than $6.2 \%$, a threshold that is significantly below the sample average of $11.7 \%$. As seen in column four, a similar result holds for cultural concerns over immigration: an increase in the unemployment rate raises the sensitivity of cultural concerns over immigration to the foreign born share of the population. In this case, however, the threshold level of the immigrant population share at which the marginal effect of unemployment on cultural concerns turns positive, $12.5 \%$, is much closer to the population average, so that on average the effect is not significantly different from zero.

In columns five to eight, we study the other macroeconomic indicator: the log per capita income. Unlike the analysis of unemployment rate, in columns five and six, we find that the association between log per capita income and economic and cultural concerns over immigration are statistically insignificant. ${ }^{13}$ In columns seven and eight, we include the interaction term between the log per capita income and the immigrant population share. The results in column seven indicate that the log per capita income affects the sensitivity of concerns over immigration to the foreignborn population share. Point estimates indicate that log per capita income decreases the economic concerns over immigration for countries in which the immigrant population share is greater than $4.64 \%$. Additionally, in the case of cultural concerns, we find that the threshold level of the immigrant population share at which the marginal effect of log per capita on cultural concerns turns positive, $19.03 \%$, is much higher than the population average.

\footnotetext{
${ }^{12}$ Espenshade et al. (1996) and Wilkes \& Corrigall-Brown (2011) find that there exists a positive association between unemployment rate and anti-immigration attitudes. However, Billiet et al. (2014) find no such relationship between unemployment rate in the time of economic crisis in 2010 and the perceived ethnic threat towards immigrants.

${ }^{13}$ Sides \& Citrin (2007), Semyonov et al. (2008), and Schneider (2008) find a negative association between GDP per capita and anti-immigration attitudes. Furthermore, Billiet et al. (2014) find that both the GDP growth rate in the time of economic crisis in 2010 as well as the change in GDP growth rate over the period from 2007-2010 significantly and negatively affect the perceived ethnic threat towards immigrants.
} 
These results strongly reject the assumption that the salience effect is independent of a country's prevailing economic conditions and provide evidence in favor of the group threat hypothesis. Note in particular that our baseline specification includes several controls for the respondent's income level and labor market status, including whether he or she was ever unemployed during last three months. Because of this the results reported in Table 7 for macroeconomic indicators should be interpreted as signs of an individual's concern for the welfare of the native population as a group, rather than as an indication of the perceived personal threat of immigration to the individual's economic situation.

Next we consider how concerns over immigration vary with the economic characteristics of the immigrant population, beginning with their employment status. To facilitate comparison across specifications, we continue to include the (total) immigrant population share in our specification, adding variables reflecting the population shares of various immigrant subgroups, including business owners, the self-employed, the unemployed and students. The omitted category is the population share comprised of employed immigrants.

Our results are shown in Table 8. Column one indicates that economic concerns over immigration are roughly equal for immigrants who are employed, unemployed, and business owners and are higher for self-employed and student immigrants. Because economic concerns over immigration appear to be similar for employed and unemployed immigrants, our results do not clearly favor either the labor market competition or welfare theories. A plausible interpretation is that both channels are present and of relatively equal strength. Our results for student and self-employed immigrants do clearly support either the welfare or competition theories.

Cultural concerns over immigration also depend on the employment status of the immigrant population in significant ways. Our findings indicate that the impact of immigrant business owners on cultural concerns over immigration is five times that of employed and self-employed immigrants. In addition, the marginal impact of unemployed immigrants is zero, $0.05910 .0567 \quad 0$. Evidence of heightened cultural concerns over economically empowered immigrants, such as business owners, is consistent with the line of group threat theory that emphasizes the role of native economic status. Unlike concerns over labor market competition, which reflect beliefs about the impact of immigration on the absolute level of native wages and incomes, concerns over economic status reflect perceived changes in relative income levels. 
To more directly test the labor market competition, we differentiate between the shares of high and low skill immigrants in the population. As seen in column one of Table 9, economic concern over immigration appears to be nearly three times as large for high skill relative to low skill immigrants. And a similar disparity is seen cultural concerns over immigration, a finding that is consistent with evidence presented in Table 8 that cultural concerns appear to be increasing in the socioeconomic status of the immigrant population. In other words, natives are more concerned towards immigration of high-skilled immigrants as compared to immigration of the low-skilled. These results contradict the findings of Hainmueller and Hiscox (2007) and Helbling and Kriesi (2014), which suggest that high-skilled immigrants are generally preferred to low-skilled immigrants.

Next we repeat this exercise using subsamples of high and low-skilled natives. Economic theory suggests that natives should be more concerned over immigrants of a similar skill level, e.g. those who would be expected to compete most directly with them in the labor market, and earlier work has found a robust link between labor market skills and preferences over immigration, with less-skilled natives preferring more restrictive immigration policy. ${ }^{14}$ Comparing columns three and five, we find that while high-skill natives are, in general, less concerned than low skill natives over the economic impact of immigration, a result that echoes the findings of Scheve and Slaughter (2001), Mayda (2006), and Hainmueller and Hiscox (2007). However, in keeping with a role for concern over labor market competition, we find that relative concern over high skill immigration is greater for high skill natives: the ratio of concern over high-skill to low-skill immigrants is greater for high skill natives, $0.121 / 0.0266=4.55$, than for low skill natives, $0.164 / 0.0731=2.24$. This finding contradicts the main findings of Hainmueller and others in two respects: 1) we find that high-skilled natives are economically concerned towards high-skilled immigration, and 2) we find that both high- as well as low-skilled natives are concerned over high-skilled immigration than they are concerned over low-skilled immigration. ${ }^{15}$

Comparing columns four and six, we find that cultural concerns over immigration are higher for low skill natives and high skill immigrants. Indeed, neither immigration skill group is a significant determinant of cultural concern over immigration for high skill natives, while low-skill natives are more concerned about high- than low-skill immigrants. These findings confirm and refine our earlier

\footnotetext{
${ }^{14}$ See, for example, Scheve \& Slaughter (2001) on skills and attitudes in the US and Hainmueller \& Hiscox (2007) on skills and attitudes in Europe.

${ }^{15}$ Hainmueller \& Hiscox (2007) show that natives with higher skills are more supportive of all types of immigration. Hainmueller \& Hopkins (2014) list number of studies that emphasize that labor market competition theory consistently fails. Hainmueller \& Hopkins (2015) demonstrate that Americans view educated immigrants in high-status jobs favorably and these preferences of Americans vary little with their education, partisanship, labor market position, ethnocentrism, or other attributes.
} 
results that cultural concerns are increasing in the socio-economic status of the immigrant population, e.g. cultural concerns of low skill natives may reflect actual or perceived loss of relative socio-economic status to the immigrant population.

In summary, we find strong evidence in support of the group threat hypothesis. A rise in the unemployment rate increases economic concerns over immigration and makes both economic and cultural concerns more sensitive to the foreign born share of the population, while an increase in real per capita income has similar but opposite effects. Evidence on the employment status of the immigrant population shows that economic concerns are greatest for students and self-employed immigrants. Economic self-interest also appears to play a role in determining how economic concerns over immigration differ for high and low skilled natives.

Our findings also suggest that economic factors play a significant role in determining cultural concerns over immigration. ${ }^{16}$ In particular cultural concerns appear to be greatest for low skill natives and for economically empowered immigrant subgroups, e.g. business owners and high skill immigrants. Thus, cultural concerns over immigration appear closely linked to the relative socio-economic status of the native population. These results are in line with Dustmann and Preston (2007), which suggests that racial and cultural prejudice is an important channel with which attitudes are formed, and is relatively important for the low-skilled citizens. Moreover, Hainmueller and Hiscox (2007) suggest that more educated respondents are significantly more likely to have immigrant friends, place greater value on cultural diversity, and as a result, are less likely to think that immigrants worsen crime problems than their less educated counterparts. A significant difference is that these studies did not distinguish between economic and cultural concerns over immigration. Another distinction is that we are able to analyze citizen's concerns as a function of different types of immigrant shares (high-skilled vs low-skilled, employed/unemployed vs business owners, Christian vs Islamic immigrants) whereas these studies heavily relied on characteristics of immigrants' origin countries to distinguish between different types of immigrants (e.g. rich and poor countries, EU and non-EU). ${ }^{17}$

\footnotetext{
${ }^{16}$ See Chandler \& Tsai (2001) and Hainmueller \& Hiscox (2007) for discussion of the relationship between education and attitudes toward immigration.

${ }^{17}$ For example, Dustmann \& Preston (2007) distinguishes immigrants on the basis of the region of their origin (such as Europe, West Indies, Australia, and South-Asia) in their analysis and study British citizens' attitudes towards immigration from these regions as a function of citizens' general labor market, welfare and cultural concerns. Hainmueller \& Hiscox (2007) use the following two distinctions: 1) GDP per capita of the country of origin to distinguish between rich and poor countries, 2) and EU and non-EU countries of origins to exploit the available attitudinal variables in the ESS dataset towards immigration from these distinctive countries. In total, Hainmueller and
} 


\section{Cultural Perspective Theory}

Next we consider how native concerns over immigration are shaped by dimensions of national culture and the cultural characteristics of the immigrant population, e.g Quillian (1995), Citrin et al. (1997), Dustmann and Preston (2007), Facchini et al. (2013), Helbling and Kriesi (2014). We focus on two dimensions of national culture, religious diversity and individualism. Contact theory suggests that a national experience of religious diversity would tend to make natives less concerned with immigration and less sensitive to increases in the immigrant share of the population, while individualism is associated with reduced attachment to group identities, which may reduce the weight given to any perceived group threat from immigration.

We rely on a single measure of each variable for each country; religious diversity is measured in 1970 and Hofstede's individualism measure is constructed from survey data collected between 1967 and 1973. Because national culture is so persistent, the use of a single of each variable is theoretically appropriate. A downside to this approach is that it precludes directly examining the effect of culture on concerns over immigration, as our cultural variables are perfectly collinear with the country fixed effects. Instead, we consider specifications in which national culture is interacted with the immigrant population share, which allows us to address how culture affects the presence or strength of salience effects.

Our results, presented in Table 10, indicate that national culture does play a significant role in shaping concerns over immigration and suggest significant international differences in the sensitivity of these concerns to the immigrant share of the population. In particular, we find that economic concerns over immigration are lower for countries with greater religious diversity and more individualistic cultures. For example, in a country with the mean level of religious diversity, 0.341, a one percent increase in the immigrant share of the population raises economic concerns by 0.0431 standard deviations. In contrast, in a country that is one standard deviation less diverse, religious diversity $=0.12$, it raises economic concerns by 0.0755 standard deviations, an effect that is seventy five percent larger. The finding that religious diversity is associated with reduced salience effects is consistent with contact theory. In particular, familiarity with one form of cultural diversity, associated with religion, appears to make natives less concerned with cultural diversity arising from immigration.

Hiscox analyze data on immigrants from 51 countries (26 EU and 25 non-EU countries) and extensively study the effect of native's education on their pro-immigration attitudes towards immigration from these EU vs non-EU and rich vs poor countries. 
Differences in individualism and collectivism have an economically significant impact on how economic concerns of country's natives respond to immigration as well. For a country with the mean level of individualism, a one percent increase in the immigrant share of the population raises economic concerns by 0.065 standard deviations. While for a country that is one standard deviation below the mean level of individualism, it raises economic concerns by 0.095 standard deviations. These results suggest that it makes little sense to talk about the effect of immigration on concerns over immigration in general, as this response depends very strongly on a country's cultural makeup.

In addition, note that religious diversity and individualism do not appear to influence the sensitivity of cultural concerns over immigration to the immigrant share of the population. In particular, the interaction effects in columns two and four are not significantly different from zero. This finding does not fit with the alignment hypothesis or with our priors. For example, we expected natives in religiously diverse countries to feel less culturally threatened by immigration than natives in more religiously homogenous countries. The fact that national culture appears to matter for salience effects in economic but not cultural concerns is a notable failure of the alignment hypothesis.

Finally, we consider how the cultural characteristics of the immigrant population affect native concerns over immigration. To measure the cultural characteristics of the immigrant population, we use the shares adhering to various world religions. In particular, we consider the share of the population composed of Christian immigrants, Muslim immigrants, immigrants of other religions and non-religious immigrants. To increase the comparability with previous results, we include the (total) share of immigrants in the population and omit the share of non-religious immigrants. The cultural perspectives theory leads us to believe that concern over immigration should be greater for non-Christian immigrants.

As seen in Table 11, the results of this exercise are largely inconclusive. None of the coefficients reflecting the religious composition of the immigrant population is significant. Thus, we cannot reject the hypothesis that the economic and cultural concerns over immigration are independent of the religious composition of the immigrant population. Our results may also reflect our reliance on the self-reported religious identity of the immigrant population, which may result in large standard errors and biased coefficients. Nevertheless, an important result here is that the fear of Islamic migrants does not show up as significant. This is found for both economic as well as cultural concerns over immigration. In columns three and four, 
we specifically focus on Islamic migrants in relation to the rest of the immigrant population. Our results suggest that native concerns over immigration are sensitive to the (total) immigrant population share, not to the share of the population comprised of Islamic immigrants. These results are in line with Strabac and Listhaug (2008), who do not find any association between the size of Muslim population in a country with the level of anti-Muslim prejudice among European population. Taken together, our results in Tables 10 and 11 suggest that it is the cultural characteristics of the native population, not the immigrant population, that determines the strength of salience effects.

\section{CONCLUSION}

This paper argues that in order to understand the links between immigration, native attitudes toward immigration and the rise of right-wing politics in Europe, it is important to distinguish between the economic and cultural dimensions of concern over immigration. In particular, we find that cultural concerns over immigration are significantly more important than economic concerns in rightwing ideological shifts and voting behavior. Motivated by this finding, the majority of the paper investigates the determinants of these two dimensions of concern.

Our second important finding is strong and consistent support for the salience hypothesis, the proposition that native concerns are increasing in the immigrant share of the population (Blalock 1967). Our work advances the large body of work that has investigated this proposition in several ways. First, we find that the immigrant share plays a substantially larger role in the formation of economic than cultural concerns over immigration. Second, by utilizing the pseudo-panel of data available from the ESS, we are able to effectively control for unobserved country and period effects that may have contaminated previous estimates based on international cross-sectional or national panel data. The ability to control for these unobserved factors should give greater confidence in our estimates of the salience effect.

In addition to placing the salience hypothesis on sounder econometric footing, we significantly refine the current understanding of the salience hypothesis, demonstrating that macroeconomic conditions and key dimensions of national culture influence the strength of salience effects. In particular, we find that economic concerns over immigration are more sensitive the immigrant population share in countries 1) with higher unemployment, 2) lower levels of per capita income, 3) less religious diversity, and 4) more collectivist cultures. In contrast, 
when considering cultural concerns over immigration, the magnitude of salience effects depends on macroeconomic conditions but not on key dimensions national culture. By highlighting systematic difference in how native attitudes respond to immigration, our results suggest caution in extrapolating results regarding attitudes toward immigration across countries or periods with different macroeconomic conditions.

Third, we provide initial evidence on the alignment hypothesis, a term we coin to refer to the idea that the economic characteristics of individuals, countries and immigrants are more important in determining economic than cultural concerns over immigration, while cultural characteristics play a greater role in determining cultural than economic concerns. Our main result here is that the alignment hypothesis holds for individual level characteristics, but not for national culture or the characteristics of the immigrant population. In particular, religious diversity and individualism appear to play a greater role in economic than cultural concern over immigration. The intriguing failure of the alignment hypothesis in this regard is a promising avenue for further study.

Another key failure of the alignment hypothesis is that cultural concern over immigration appears to be highly sensitive to the economic characteristics of the immigrant population. In particular, cultural concern is increasing with the population share of economically empowered immigrants, such as business owners and high-skill immigrants, a finding we interpret this finding as consistent with native concerns over economic status. To the best of our knowledge, the idea that native concerns over immigration would respond to changes in relative income, rather than absolute income, has not been previously investigated in the literature on attitudes toward immigration, though a taste for status has emerged as a central finding in investigations of subjective wellbeing.

In closing we wish to highlight two implications of our findings for the literature on attitudes toward immigration. First, our results provide support for two of the three the primary theories of attitudes toward immigration. Consistent with group threat theory, we find that both forms of concern are increasing in the immigrant population share and are greater in difficult economic conditions. Consistent with cultural perspectives theory, we find that economic concerns over immigration depend on individual and national cultural variable. In particular, we find that salience effects are stronger for countries with more religiously homogeneous populations and collectivist cultures. In contrast with earlier work, we highlight the importance of the cultural characteristics of the native, rather than immigrant, 
population. Collectively, our findings suggest that group threat and cultural theories may best be viewed as complements.

Second, our results call for explicit examination of how immigration policy affects attitudes toward immigrants. In particular, the failure of the alignment hypothesis with respect to country-level variables suggests that policies designed to address one dimension of concerns may spillover (positively or negatively) on the other dimension. For example, policy changes designed to increase the share of high-skill immigrants or increase immigrant labor market attachment may decrease economic concerns while increasing cultural concerns. The net effect of such changes on attitudes toward immigration, and their implications for support for right-wing policies and political parties, remains an important subject for future investigation.

\section{References:}

OECD. International Migration Outlook 2014, OECD Publishing, Paris, 2014.

The Economist, “Turning Right,” (Jan 4, 2014).

Alesina, Alberto, and Paola Giuliano. "Culture and Institutions." Journal of Economic Literature (Forthcoming).

Billet, Jaak, and Hans De Witte. "Attitudinal Dispositions to Vote for a 'new' Extreme Right-Wing Party: The Case of 'Vlaams Blok."” European Journal of Political Research 27 (1995): 181-202.

Billet, Jaak, Bart Meuleman, and Hans De Witte. "The Relationship between Ethnic Threat and Economic Insecurity in Times of Economic Crisis: Analysis of European Social Survey Data." Migration Studies, 2014,

Blalock, Hubert M. Toward a Theory of Minority-Group Relations. A Capricorn Giant. Wiley, 1967.

Blumer, Herbert. "Race Prejudice as a Sense of Group Position." The Pacific Sociological Review 1, no. 1 (1958): 3-7.

Ceobanu, Alin M. “Usual Suspects? Public Views about Immigrants' Impact on Crime in European Countries." International Journal of Comparative Sociology 52, no. 1-2 (2010): 114-31. 
Chandler, Charles R., and Yung-mei Tsai. "Social Factors Influencing Immigration Attitudes: An Analysis of Data from the General Social Survey." The Social Science Journal 38, no. 2 (2001): 177-88.

Citrin, Jack, Donald P. Green, Christopher Muste, and Cara Wong. "Public Opinion Toward Immigration Reform: The Role of Economic Motivations." The Journal of Politics 59, no. 03 (1997): 858.

Clark, Andrew E, Paul Frijters, and Michael A Shields. "Relative Income, Happiness, and Utility: An Explanation for the Easterlin Paradox and Other Puzzles." Journal of Economic Literature 46, no. 1 (2008): 95-144.

Davis, Lewis S, and Matthew Knauss. "The Moral Consequences of Economic Growth: An Empirical Investigation.” The Journal of Socio-Economics 42 (2013): 43-50.

Dustmann, Christian, and Ian Preston. "Attitudes to Ethnic Minorities, Ethnic Context and Location Decisions.” Economic Journal 111, no. 470 (2001): 353-73.

. "Is Immigration Good or Bad for the Economy? Analysis of Attitudinal Responses." In The Economics of Immigration and Social Diversity, 24:3-34. Research in Labor Economics. Emerald Group Publishing Limited, 2006.

_ "Racial and Economic Factors in Attitudes to Immigration." The B.E. Journal of Economic Analysis \& Policy 7, no 1 (2007): Article 62.

Espenshade, Thomas J, Katherine Hempstead. "Contemporary American Attitudes Toward U.S. Immigration." International Migration Review 30, No. 2 (1996): 535-570.

Evans, Geoffrey, and Ariana Need. "Explaining Ethnic Polarization over Attitudes towards Minority Rights in Eastern Europe : A Multilevel Analysis" Social Science Research 31, (2002): 653-80.

Facchini, Giovanni, and Anna Maria Mayda. "Does the Welfare State Affect Individual Attitudes toward Immigrants? Evidence across Countries." Review of Economics and Statistics 91, no. 2 (2009): 295-314.

_. "From Individual Attitudes towards Migrants to Migration Policy Outcomes: Theory and Evidence." In Economic Policy, 653-714. Blackwell Publishing Ltd., 2008.

Facchini, Giovanni, Anna Maria Mayda, and Mariapia Mendola. "What Drives Individual Attitudes towards Immigration in South Africa?" Review of International Economics 21, no. 2 (2013): 326-41. 
Facchini, Giovanni, Anna Maria Mayda, and Prachi Mishra. "Do Interest Groups Affect US Immigration Policy?" Journal of International Economics 85, no. 1 (2011): 11428.

Friedman, Benjamin M. The Moral Consequences of Economic Growth. New York: Alfred A. Knopf, 2005.

Gang, Ira N., Francisco L. Rivera-Batiz, and Myeng Su Yun. "Economic Strain, Education and Attitudes towards Foreigners in the European Union." Review of International Economics 21, no. 2 (2013): 177-90.

Gorodnichenko, Yuriy, and Gerard Roland. "Which Dimensions of Culture Matter for Long-Run Growth?” The American Economic Review 101, no. 3 (2011): 492-98.

Guiso, Luigi, Paola Sapienza, and Luigi Zingales. "Does Culture Affect Economic Outcomes?" Journal of Economic Perspectives 20, no. 2 (2006): 23-48.

__ "People's Opium? Religion and Economic Attitudes." Journal of Monetary Economics 50, no. 1 (January 2003): 225-82.

Hainmueller, Jens, and Michael J. Hiscox. "Educated Preferences: Explaining Attitudes Toward Immigration in Europe." International Organization 61, no. 02 (2007).

Hainmueller, Jens, and Daniel J Hopkins. "The Hidden American Immigration Consensus: A Conjoint Analysis of Attitudes toward Immigrants." American Journal of Political Science 59, no. 3 (2015): 529-48.

_. "Public Attitudes Toward Immigration." Annual Review of Political Science 17, no. 1 (2014): 225-49.

Halla, Martin, Alexander Wagner, and Josef Zweimüller. Does Immigration into Their Neighborhoods Incline Voters Toward the Extreme Right? The Case of the Freedom Party of Austria. IZA Discussion papers No. 6575 (2012).

Helbling, Marc, and Hanspeter Kriesi. "Why Citizens Prefer High- Over Low-Skilled Immigrants. Labor Market Competition, Welfare State, and Deservingness." European Sociological Review 0, no. 0 (2014): 1-20.

Hofstede, Geert H. Culture's Consequences: Comparing Values, Behaviors, Institutions and Organizations Across Nations. SAGE Publications, 2001.

_. "The Interaction Between National and Organizational Value Systems[1]." Journal of Management Studies 22, no. 4 (1985): 347-57. 
Ivarsflaten, Elisabeth. "Reputational Shields: Why Most Anti-Immigrant Parties Failed in Western Europe, 1980-2005.” Annual Meeting of the American Political Science Association, 2006, 1-24.

Jolly, Seth K., and Gerald M. DiGiusto. "Xenophobia and Immigrant Contact: French Public Attitudes toward Immigration.” Social Science Journal 51, no. 3 (2014): 464-73.

Knabe, Andreas, Steffen Rätzel, and Stephan L Thomsen. "Right-Wing Extremism and the Well-Being of Immigrants.” Kyklos 66, no. 4 (2013): 567-90.

Lubbers, Marcel, Mérove Gijsberts, and Peer Scheepers. "Extreme Right-Wing Voting in Western Europe.” European Journal of Political Research 41, no. 3 (2002): 345-78.

Mayda, Anna Maria. "Who Is Against Immigration? A Cross-Country Investigation of Individual Attitudes toward Immigrants." Review of Economics and Statistics 88, no. 3 (2006): 510-30.

McCleary, Rachel M, and Robert J Barro. "Religion and Economy." Journal of Economic Perspectives 20, no. 2 (2006): 49-72.

Mudde, Cas. "The Relationship Between Immigration and Nativism in Europe and North America.” Migration Policy Institute, 2012.

_ . "Three Decades of Populist Radical Right Parties in Western Europe: So What?" European Journal of Political Research 52, no. 1 (2013): 1-19.

O’Rourke, Kevin H., and Richard Sinnott. "The Determinants of Individual Attitudes towards Immigration.” European Journal of Political Economy 22, no. 4 (2006): 838-61.

Oliver, J., and Wong, J. "Intergroup prejudice in multiethnic settings." American Journal of Political Science 47, no. 4 (2003): 567-582.

Quillian, Lincoln. "Prejudice as a Response to Perceived Group Threat: Population Composition and Anti-Immigrant and Racial Prejudice in Europe." American Sociological Review 60, no. 4 (1995): 586.

Rydgren, Jens. "Immigration Sceptics, Xenophobes or Racists? Radical Right-Wing Voting in Six West European Countries." European Journal of Political Research 47, no. 6 (2008): 737-65.

Scheve, Kenneth F., and Matthew J. Slaughter. "Labor Market Competition and Individual Preferences Over Immigration Policy." Review of Economics and Statistics 83, no. 1 (2001): 133-45. 
Schneider, Silke L. "Anti-Immigrant Attitudes in Europe: Outgroup Size and Perceived Ethnic Threat." European Sociological Review 24, no. 1 (2008): 53-67.

Semyonov, M., R. Raijman, and a. Gorodzeisky. "Foreigners' Impact on European Societies: Public Views and Perceptions in a Cross-National Comparative Perspective." International Journal of Comparative Sociology 49, no. 1 (2008): 529.

Semyonov, Moshe, Rebeca Raijman, Anat Yom Tov, and Peter Schmidt. "Population Size, Perceived Threat, and Exclusion: A Multiple-Indicators Analysis of Attitudes toward Foreigners in Germany." Social Science Research 33, no. 4 (2004): 681-701.

Senik, Claudia, Holger Stichnoth, and Karine Van der Straeten. "Immigration and Natives' Attitudes towards the Welfare State: Evidence from the European Social Survey." Social Indicators Research 91, no. 3 (2009): 345-70.

Sides, John, and Jack Citrin. "European Opinion About Immigration: The Role of Identities, Interests and Information." British Journal of Political Science 37, no. 03 (2007): 477.

Strabac, Zan, and Ola Listhaug. "Anti-Muslim Prejudice in Europe: A Multilevel Analysis of Survey Data from 30 Countries.” Social Science Research 37, no. 1 (2008): 268-86.

Vallas, Steven P., Emily Zimmerman, and Shannon N. Davis. "Enemies of the State? Testing Three Models of Anti-Immigrant Sentiment." Research in Social Stratification and Mobility 27, no. 4 (2009): 201-17.

Wilkes, R., and C. Corrigall-Brown. "Explaining Time Trends in Public Opinion: Attitudes towards Immigration and Immigrants." International Journal of Comparative Sociology 52, no. 1-2 (2011): 79-99.

Zimmermann, Klaus F., Thomas Bauer, and Magnus Lofstrom. "Immigration Policy, Assimilation of Immigrants and Natives' Sentiments towards Immigrants: Evidence from 12 OECD-Countries." Swedish Economic Policy Review 7 (2000): 11-53. 
Table 1: Vote shares of far-right parties in the European Parliamentary elections

\begin{tabular}{llccccc}
\hline \hline Countries & Parties & $\mathbf{1 9 9 4}$ & $\mathbf{1 9 9 9}$ & $\mathbf{2 0 0 4}$ & $\mathbf{2 0 0 9}$ & $\mathbf{2 0 1 4}$ \\
\hline Austria & Freiheitliche Partei Osterreichs** & 27.5 & 23.4 & 6.3 & 12.7 & 19.72 \\
Denmark & Dansk Folkeparti &. & 5.8 & 6.8 & 15.3 & 26.60 \\
Finland & Perussuomalaiset** & 0.67 & 0.79 & 0.54 & 9.79 & 12.90 \\
France & Front National & 10.5 & 5.7 & 9.8 & 6.3 & 24.86 \\
Italy & Lega Nord & 6.5 & 4.5 & 5 & 10.2 & 6.16 \\
Netherlands & Partij voor de Vrijheid &. &. &. & 17 & 13.32 \\
Sweden & Sverigedemokraterna &. & 0.3 & 1.1 & 3.3 & 9.70 \\
United Kingdom & United Kingdom Independence Party & 1 & 6.7 & 16.1 & 16.6 & 26.77 \\
\hline \hline Note: *: This is an incomplete list of political parties with far-right election agendas. Parties only with substantial \\
vote shares (about 10 perc. of total vote share) are included. **: European parliament elections in Austria and \\
Finland took place in the year 1996 rather than 1994. Data source: European Election Database.
\end{tabular}


Table 2: Descriptive Statistics

\begin{tabular}{|c|c|c|c|}
\hline Variable & Mean & (Std. Dev.) & (Obs \#) \\
\hline \multicolumn{4}{|l|}{ Attitudes (on a scale between 1-11) } \\
\hline Immigration bad for country's economy (EC) & 6.180724 & 2.36868 & 167305 \\
\hline Immigrants undermine culture $(\mathrm{CC})$ & 5.438796 & 2.470954 & 167734 \\
\hline Placement on the left-right scale (Right) & 6.095417 & 2.12198 & 153788 \\
\hline Voted & .7535038 & .430972 & 173739 \\
\hline Voted to a right-wing party & .0512855 & .2205806 & 96694 \\
\hline \multicolumn{4}{|l|}{ Demographics } \\
\hline Female & 0.5331848 & 0.498899 & 175095 \\
\hline Age & 47.69723 & 18.55659 & 174418 \\
\hline Married & 0.5053786 & 0.4999725 & 175324 \\
\hline Urban & 0.3074943 & 0.4614572 & 174787 \\
\hline Living with children & .3781282 & .4849212 & 174663 \\
\hline Belong to an Ethnic minority & .0308121 & .1728088 & 172984 \\
\hline \multicolumn{4}{|l|}{ Economic Factors } \\
\hline Education & 12.06375 & 4.098498 & 173371 \\
\hline HH Income & 5.943093 & 2.667264 & 127665 \\
\hline Employee & .8611097 & .3458331 & 157376 \\
\hline Owner & .0151357 & .1220931 & 157376 \\
\hline Retired & .2520305 & .4341799 & 175324 \\
\hline Self-employed & .1237546 & .3293024 & 157376 \\
\hline Unemployed for last 3 months & .2445703 & .4298334 & 174412 \\
\hline \multicolumn{4}{|l|}{ Cultural Factors } \\
\hline Father Immigrant & .076591 & .2659422 & 174446 \\
\hline Mother Immigrant & .0757176 & .2645464 & 174900 \\
\hline Islam & .007278 & .0850002 & 175324 \\
\hline Catholic & .3543554 & .4783189 & 175324 \\
\hline Protestant & .1644783 & .3707101 & 175324 \\
\hline Eastern Orthodox & .0532671 & .2245662 & 175324 \\
\hline Jew & .00077 & .0277383 & 175324 \\
\hline Other Christian Religions & .0145331 & .1196744 & 175324 \\
\hline Eastern Religions & .0026351 & .0512659 & 175324 \\
\hline Other religions & .0022701 & .0475914 & 175324 \\
\hline Religiosity & 5.709478 & 2.984233 & 173925 \\
\hline \multicolumn{4}{|c|}{$\begin{array}{l}\text { Note: This table summarizes individual's concerns towards immigration and his political alignment towards } \\
\text { the right on the political scale. These attitudinal variables are reported on a scale from } 1 \text { to } 11 \text { ( } 1 \text { being } \\
\text { the lowest). Variable Female takes a value of } 1 \text { if the respondent has reported her gender as female and } 0 \\
\text { otherwise. Similarly, the dummy variables representing marital status of the respondent takes value of } 1 \\
\text { if the respondent has reported to be married, single, divorced, separated, and widowed, and } 0 \text { otherwise. } \\
\text { Variable voted takes a value } 1 \text { if the respondent reports that he has voted in the last national elections, } \\
\text { and } 0 \text { otherwise. Variable HH Size and HH income indicate the total number of individuals that live in } \\
\text { the household and their total income. Variables indicating employment relation of the respondent take } \\
\text { value of } 1 \text { if the respondent reports himself/herself as an employee or owner or retired or self-employed } \\
\text { personnel and } 0 \text { otherwise. Variables indicating respondent's religious beliefs take a value of } 1 \text { if respondent } \\
\text { has reported his/her religion as Islam, Catholic, Protestant, Eastern Orthodox, Jew, etc, and } 0 \text { otherwise. } \\
\text { Variable Born in this country takes a value of } 1 \text { if the respondent was born in the country where he/she } \\
\text { currently resides. }\end{array}$} \\
\hline
\end{tabular}


Table 3: Selected Macro Indicators

\begin{tabular}{|c|c|c|c|c|c|}
\hline & (1) & (2) & (3) & (4) & (5) \\
\hline Variables & Mean & (Std. Dev.) & Min & Max & Obs \# \\
\hline Immigrant Share in perc.(OECD) & 11.738 & 6.854 & 2 & 35.3 & 146667 \\
\hline Immigrant Share in perc. (ESS) & 8.91933 & 7.0818 & 0.9985 & 23.43 & 175324 \\
\hline Unemployment Rate in perc. (OECD) & 7.596 & 3.6112 & 2.55 & 20.06 & 174243 \\
\hline GDP Per capita (OECD) & 32359.38 & 11031.98 & 11591.8 & 65148.4 & 175324 \\
\hline Hofstede's Measure of Individualism & 63.33 & 14.76572 & 27 & 89 & 168234 \\
\hline Herfindahl Index of religion shares for year 1970 & 0.659 & 0.221 & .324146 & .948976 & 175324 \\
\hline Plurality Index for year 1970 (=1-Herfindahl1970) & 0.341 & 0.221 & .051024 & .675854 & 175324 \\
\hline \multicolumn{6}{|l|}{ Immigrant Shares (calc from ESS) } \\
\hline \multicolumn{6}{|l|}{ Job type and Immigrant Shares } \\
\hline Employee Immigrants (in \%) & 9.88636 & 5.367308 & 1.56396 & 33.66642 & 146667 \\
\hline Owner Immigrants (in \%) & .1914371 & .1208149 & .045851 & .6498864 & 108687 \\
\hline Self-employed Immigrants (in \%) & 1.184375 & .704403 & .0964171 & 4.164918 & 143776 \\
\hline Unemployed Immigrants (in \%) & 3.601908 & 1.624802 & .1336502 & 7.329916 & 146667 \\
\hline Student Immigrants (in \%) & .9937738 & .4930908 & .0975 & 2.8269 & 138827 \\
\hline \multicolumn{6}{|l|}{ Education and Immigrant Shares } \\
\hline High-educated Immigrants (in \%) & 2.940468 & 1.573881 & .2432432 & 7.471941 & 144557 \\
\hline Low-educated Immigrants (in \%) & 7.433151 & 4.341639 & 1.749206 & 27.39918 & 146667 \\
\hline \multicolumn{6}{|l|}{ Religion and Immigrant Shares } \\
\hline Christian Immigrants (in \%) & 5.43629 & 3.425587 & 1.519048 & 21.96284 & 146667 \\
\hline Islamic Immigrants (in \%) & 1.444358 & .8642955 & .0547855 & 4.332 & 121249 \\
\hline Immigrants from other religions (in \%) & .4010341 & .2805022 & .0460317 & 1.368 & 124678 \\
\hline Non-religious Immigrants (in \%) & 4.049758 & 2.307179 & .0669843 & 10.36896 & 146667 \\
\hline \multicolumn{6}{|c|}{$\begin{array}{l}\text { Dote: Immigrant Share is the share of foreign born as a fraction of total population of the country. We have the data on Immigrant } \\
\text { Share belonging to two distinct sources: OECD and ESS. The variable unemployment rate is a fraction of total population who is } \\
\text { reported to be unemployed in the sample countries. The Herfindahl index of religion shares and the Hofstede Measure of individualism } \\
\text { are the two independent measures borrowed from the sources as mentioned in the description. The variable Employee immigrants is } \\
\text { the share of foreign born in the survey population who reported their current job type as Employee. Similarly, ESS provides data on } \\
\text { the foreign born in the survey population who reported their current job type as owners, self-employed, unemployed, and students. } \\
\text { Highly-educated immigrant variable represents the immigrant population (foreign born) among the survey population with education } \\
\text { more than } 15 \text { years. Christian and Islamic immigrants represent the share of population which is foreign-born and belong to Christian } \\
\text { (catholic, protestant, eastern orthodox and other Christian) and Islamic religions. }\end{array}$} \\
\hline
\end{tabular}

Table 4: Concerns over Immigration and Right-ward Political Ideology

\begin{tabular}{|c|c|c|c|c|c|c|}
\hline & (1) & $(2)$ & (3) & (4) & (5) & (6) \\
\hline Variables & Ideology & Ideology & Ideology & RightVote & RightVote & RightVote \\
\hline \multirow[t]{2}{*}{$\mathrm{EC}$} & $0.102^{* * *}$ & & $0.0267^{*}$ & $0.329 * * *$ & & $0.188^{* * *}$ \\
\hline & $(4.51)$ & & $(1.88)$ & $(10.84)$ & & $(6.10)$ \\
\hline \multirow[t]{2}{*}{$\mathrm{CC}$} & & $0.154^{* * *}$ & $0.139 * * *$ & & $0.352^{* * *}$ & $0.245^{* * *}$ \\
\hline & & $(6.52)$ & $(7.71)$ & & $(14.84)$ & $(12.69)$ \\
\hline Individual Controls & YES & YES & YES & YES & YES & YES \\
\hline Country Controls & YES & YES & YES & YES & YES & YES \\
\hline Year Controls & YES & YES & YES & YES & YES & YES \\
\hline \multirow[t]{2}{*}{ Constant } & 0.202 & 0.160 & 0.143 & $-1.582^{* * *}$ & $-1.467^{* * *}$ & $-1.603^{* * *}$ \\
\hline & $(1.54)$ & $(1.31)$ & $(1.21)$ & $(-5.70)$ & $(-5.25)$ & $(-6.14)$ \\
\hline R-Squared & 0.1119 & 0.1221 & 0.1225 & & & \\
\hline Observations & 83054 & 83054 & 83054 & 64040 & 64040 & 64040 \\
\hline
\end{tabular}

reported by the respondent. The analysis for right wing voting decision considers the following 17 out of 22 countries: Austria, Belgium, Bulgaria, Switzerland, Denmark, Germany, Finland, France, Great Britain, Greece, Croatia, Hungary, Italy, Netherlands, Norway, Portugal and Sweden. t statistics in parentheses: ${ }^{*} \mathrm{p}<0.10, * * \mathrm{p}<0.05,{ }^{* * *} \mathrm{p}<0.01$ 
Table 5: Immigrant Share and Concerns

\begin{tabular}{|c|c|c|c|}
\hline Variables & $\begin{array}{l}\text { (1) } \\
\text { EC }\end{array}$ & $\begin{array}{l}(2) \\
\mathrm{CC}\end{array}$ & $\begin{array}{c}(3) \\
\text { EC-CC }\end{array}$ \\
\hline Immigrant Share & $\begin{array}{c}0.0853^{* * *} \\
(3.54)\end{array}$ & $\begin{array}{c}0.0311^{* * *} \\
(3.38)\end{array}$ & $\begin{array}{c}0.0542^{* * *} \\
(2.85)\end{array}$ \\
\hline Female & $\begin{array}{c}0.134^{* * *} \\
(9.84)\end{array}$ & $\begin{array}{c}-0.0218 \\
(-0.74)\end{array}$ & $\begin{array}{c}0.156 * * * \\
(5.57)\end{array}$ \\
\hline Age & $\begin{array}{c}-0.00689^{* *} \\
(-2.59)\end{array}$ & $\begin{array}{c}-0.00510 \\
(-1.14)\end{array}$ & $\begin{array}{c}-0.00180 \\
(-0.46)\end{array}$ \\
\hline Age-squared & $\begin{array}{c}0.0000333 \\
(1.54)\end{array}$ & $\begin{array}{c}0.0000496 \\
(1.09)\end{array}$ & $\begin{array}{c}-0.0000163 \\
(-0.39)\end{array}$ \\
\hline Married & $\begin{array}{c}0.0283^{* * *} \\
(2.93)\end{array}$ & $\begin{array}{c}0.0587^{* * *} \\
(2.98)\end{array}$ & $\begin{array}{c}-0.0304^{* *} \\
(-2.09)\end{array}$ \\
\hline Urban & $\begin{array}{c}-0.0877^{* * *} \\
(-6.09)\end{array}$ & $\begin{array}{c}-0.0827 * * * \\
(-7.57)\end{array}$ & $\begin{array}{c}-0.00500 \\
(-0.74)\end{array}$ \\
\hline Living with children & $\begin{array}{c}0.0199^{* *} \\
(2.15)\end{array}$ & $\begin{array}{c}-0.00561 \\
(-0.57)\end{array}$ & $\begin{array}{c}0.0255^{*} \\
(2.00)\end{array}$ \\
\hline Education & $\begin{array}{c}-0.0568 * * * \\
(-9.17)\end{array}$ & $\begin{array}{c}-0.0566^{* * *} \\
(-7.21)\end{array}$ & $\begin{array}{c}-0.000242 \\
(-0.12)\end{array}$ \\
\hline $\mathrm{HH}$ Income & $\begin{array}{c}-0.0345^{* * *} \\
(-7.44)\end{array}$ & $\begin{array}{c}-0.0315^{* * *} \\
(-8.45)\end{array}$ & $\begin{array}{c}-0.00295 \\
(-1.03)\end{array}$ \\
\hline Owner & $\begin{array}{c}-0.0257 \\
(-0.79)\end{array}$ & $\begin{array}{l}0.0291 \\
(0.67)\end{array}$ & $\begin{array}{c}-0.0549 * * \\
(-2.45)\end{array}$ \\
\hline Retired & $\begin{array}{l}0.0251 \\
(1.12)\end{array}$ & $\begin{array}{l}0.0260 \\
(1.06)\end{array}$ & $\begin{array}{c}-0.000904 \\
(-0.08)\end{array}$ \\
\hline Self-employed & $\begin{array}{c}-0.0307^{* *} \\
(-2.13)\end{array}$ & $\begin{array}{c}-0.00152 \\
(-0.07)\end{array}$ & $\begin{array}{c}-0.0292^{* *} \\
(-2.31)\end{array}$ \\
\hline Unemployed for 3 months & $\begin{array}{c}0.0392^{*} \\
(1.73)\end{array}$ & $\begin{array}{c}-0.00336 \\
(-0.16)\end{array}$ & $\begin{array}{c}0.0426^{* * *} \\
(5.01)\end{array}$ \\
\hline Immigrant father & $\begin{array}{c}-0.114^{* * *} \\
(-5.05)\end{array}$ & $\begin{array}{c}-0.0711^{* * *} \\
(-3.31)\end{array}$ & $\begin{array}{c}-0.0425 \\
(-1.50)\end{array}$ \\
\hline Immigrant mother & $\begin{array}{c}-0.0898^{* * *} \\
(-4.10)\end{array}$ & $\begin{array}{c}-0.111^{* * *} \\
(-3.11)\end{array}$ & $\begin{array}{l}0.0212 \\
(0.62)\end{array}$ \\
\hline Islam & $\begin{array}{c}-0.425^{* * *} \\
(-4.05)\end{array}$ & $\begin{array}{c}-0.537^{* * *} \\
(-7.25)\end{array}$ & $\begin{array}{l}0.112 \\
(1.39)\end{array}$ \\
\hline Catholic & $\begin{array}{c}0.0751^{* *} \\
(2.17)\end{array}$ & $\begin{array}{c}0.136^{* * * *} \\
(8.16)\end{array}$ & $\begin{array}{c}-0.0609 * * \\
(-2.60)\end{array}$ \\
\hline Protestant & $\begin{array}{l}0.0318 \\
(0.97)\end{array}$ & $\begin{array}{l}0.0720 \\
(1.65)\end{array}$ & $\begin{array}{c}-0.0402^{* *} \\
(-2.31)\end{array}$ \\
\hline Eastern orthodox & $\begin{array}{l}0.184 \\
(1.58)\end{array}$ & $\begin{array}{c}0.278^{* * *} \\
(3.26)\end{array}$ & $\begin{array}{c}-0.0944 \\
(-0.93)\end{array}$ \\
\hline Jew & $\begin{array}{c}-0.149^{* *} \\
(-2.12)\end{array}$ & $\begin{array}{l}0.0534 \\
(1.01)\end{array}$ & $\begin{array}{c}-0.202 * * * \\
(-4.27)\end{array}$ \\
\hline Other christian religion & $\begin{array}{c}-0.0286 \\
(-0.73)\end{array}$ & $\begin{array}{c}0.00695 \\
(0.22)\end{array}$ & $\begin{array}{c}-0.0355 \\
(-0.68)\end{array}$ \\
\hline Eastern religion & $\begin{array}{c}-0.0974 \\
(-1.53)\end{array}$ & $\begin{array}{c}-0.272^{* * *} \\
(-3.16)\end{array}$ & $\begin{array}{c}0.175^{* * *} \\
(3.26)\end{array}$ \\
\hline Other religion & $\begin{array}{c}-0.00814 \\
(-0.11)\end{array}$ & $\begin{array}{l}-0.113 \\
(-0.81)\end{array}$ & $\begin{array}{l}0.105 \\
(1.31)\end{array}$ \\
\hline From an ethnic minority & $\begin{array}{c}-0.0627 * * * \\
(-3.53)\end{array}$ & $\begin{array}{c}-0.0345 \\
(-1.43)\end{array}$ & $\begin{array}{l}-0.0282 \\
(-1.04)\end{array}$ \\
\hline Religiosity & $\begin{array}{c}-0.0137 * * * \\
(-2.95)\end{array}$ & $\begin{array}{c}-0.0118 \\
(-1.67)\end{array}$ & $\begin{array}{c}-0.00196 \\
(-0.57)\end{array}$ \\
\hline Year Controls & YES & YES & YES \\
\hline Country Controls & YES & YES & YES \\
\hline Constant & $\begin{array}{c}-2.329^{* *} \\
(-2.81)\end{array}$ & $\begin{array}{l}-0.458 \\
(-1.30)\end{array}$ & $\begin{array}{c}-1.871^{* * *} \\
(-2.99)\end{array}$ \\
\hline F-test for Eco Factors & 28.53 & 19.64 & 19.02 \\
\hline F-test for Cult Factors & 88.28 & 137.50 & 51.43 \\
\hline R-Squared & 0.1294 & 0.1542 & 0.0547 \\
\hline Observations & 93546 & 93546 & 93546 \\
\hline \multicolumn{4}{|c|}{$\begin{array}{l}\text { Note: The dependent variables used in this table are: EC - Immigrants } \\
\text { are bad for economy, CC - Immigrants undermine culture, and EC-CC - } \\
\text { The difference between respondent's economic concerns (EC) and cultural } \\
\text { concerns (CC) towards immigration. In order to relate our findings with } \\
\text { regards to citizen level determinants of these concerns, we show all the } \\
\text { individual level controls uniquely in this table. t statistics in parentheses: } \\
{ }^{*} \mathrm{p}<0.10,{ }^{*} \mathrm{p}<0.05, * * * \mathrm{p}<0.01\end{array}$} \\
\hline
\end{tabular}


Table 6: Robustness Checks

\begin{tabular}{|c|c|c|c|c|c|c|}
\hline Variables & $\begin{array}{c}\text { Full sample } \\
\text { (1) } \\
\text { EC }\end{array}$ & $\begin{array}{c}\text { Full sample } \\
(2) \\
\text { CC }\end{array}$ & $\begin{array}{c}\text { Conti. Europe } \\
(3) \\
\text { EC }\end{array}$ & $\begin{array}{c}\text { Conti. Europe } \\
\text { (4) } \\
\text { CC }\end{array}$ & $\begin{array}{c}\text { Full sample } \\
(5) \\
\text { EC }\end{array}$ & $\begin{array}{c}\text { Full sample } \\
(6) \\
\text { CC }\end{array}$ \\
\hline Immigrant Share & $\begin{array}{c}0.0710^{* * *} \\
(3.46)\end{array}$ & $\begin{array}{c}0.0282^{* * *} \\
(3.69)\end{array}$ & $\begin{array}{c}0.0801^{* * *} \\
(3.43)\end{array}$ & $\begin{array}{c}0.0316^{* * *} \\
(3.32)\end{array}$ & $\begin{array}{c}0.114^{* *} \\
(2.53)\end{array}$ & $\begin{array}{c}0.0435^{* * *} \\
(3.08)\end{array}$ \\
\hline Immigrant Share Squared & & & & & $\begin{array}{c}-0.00112 \\
(-0.60)\end{array}$ & $\begin{array}{c}-0.000494 \\
(-0.89)\end{array}$ \\
\hline Individual Controls & YES & YES & YES & YES & YES & YES \\
\hline Country Time Trend & YES & YES & $\mathrm{NO}$ & $\mathrm{NO}$ & $\mathrm{NO}$ & $\mathrm{NO}$ \\
\hline Country Controls & $\mathrm{NO}$ & $\mathrm{NO}$ & YES & YES & YES & YES \\
\hline Year Controls & $\mathrm{NO}$ & $\mathrm{NO}$ & YES & YES & YES & YES \\
\hline Constant & $\begin{array}{c}60.56^{* * *} \\
(3.20)\end{array}$ & $\begin{array}{l}5.940 \\
(0.62)\end{array}$ & $\begin{array}{c}-2.180^{* *} \\
(-2.72)\end{array}$ & $\begin{array}{l}-0.452 \\
(-1.24)\end{array}$ & $\begin{array}{l}-1.970 \\
(-1.71)\end{array}$ & $\begin{array}{l}-0.300 \\
(-0.70)\end{array}$ \\
\hline R-squared & 0.1279 & 0.1527 & 0.1257 & 0.1501 & 0.1295 & 0.1543 \\
\hline Observations & 93546 & 93546 & 83505 & 83505 & 93546 & 93546 \\
\hline
\end{tabular}

Table 7: Macroeconomic channels that shapes Concerns

\begin{tabular}{|c|c|c|c|c|c|c|c|c|}
\hline & (1) & (2) & (3) & (4) & (5) & (6) & (7) & (8) \\
\hline Variables & EC & $\mathrm{CC}$ & EC & $\mathrm{CC}$ & EC & $\mathrm{CC}$ & EC & $\mathrm{CC}$ \\
\hline Immigrant Share (MS) & $\begin{array}{c}0.0441^{* *} \\
(2.63)\end{array}$ & $\begin{array}{c}0.0285^{* *} \\
(2.73)\end{array}$ & $\begin{array}{c}-0.00868 \\
(-0.32)\end{array}$ & $\begin{array}{c}0.00879 \\
(0.58)\end{array}$ & $\begin{array}{c}0.0828^{* * *} \\
(3.54)\end{array}$ & $\begin{array}{c}0.0318^{* * *} \\
(3.39)\end{array}$ & $\begin{array}{c}0.707^{* * *} \\
(3.68)\end{array}$ & $\begin{array}{c}0.195^{* *} \\
(2.16)\end{array}$ \\
\hline Unemployment Rate & $\begin{array}{c}0.0355^{* * *} \\
(11.10)\end{array}$ & $\begin{array}{c}0.00217 \\
(0.80)\end{array}$ & $\begin{array}{c}-0.0292 \\
(-1.53)\end{array}$ & $\begin{array}{c}-0.0220^{*} \\
(-1.85)\end{array}$ & & & & \\
\hline MS*Unemp & & & $\begin{array}{c}0.00471^{* * *} \\
(3.34)\end{array}$ & $\begin{array}{c}0.00176^{*} \\
(2.05)\end{array}$ & & & & \\
\hline $\log ($ GDP per capita $)$ & & & & & $\begin{array}{l}-0.419 \\
(-0.58)\end{array}$ & $\begin{array}{l}0.114 \\
(0.38)\end{array}$ & $\begin{array}{l}0.277 \\
(0.38)\end{array}$ & $\begin{array}{l}0.295 \\
(0.91)\end{array}$ \\
\hline MS* $\log ($ GDP per capita $)$ & & & & & & & $\begin{array}{c}-0.0596^{* * *} \\
(-3.27)\end{array}$ & $\begin{array}{c}-0.0155^{*} \\
(-1.77)\end{array}$ \\
\hline Individual Controls & YES & YES & YES & YES & YES & YES & YES & YES \\
\hline Country Controls & YES & YES & YES & YES & YES & YES & YES & YES \\
\hline Year Controls & YES & YES & YES & YES & YES & YES & YES & YES \\
\hline Constant & $\begin{array}{c}0.421^{* * *} \\
(3.06) \\
\end{array}$ & $\begin{array}{c}0.825^{* * *} \\
(5.72) \\
\end{array}$ & $\begin{array}{c}1.440^{* * *} \\
(3.98) \\
\end{array}$ & $\begin{array}{c}1.206^{* * *} \\
(4.30)\end{array}$ & $\begin{array}{l}2.377 \\
(0.31) \\
\end{array}$ & $\begin{array}{l}-1.734 \\
(-0.51) \\
\end{array}$ & $\begin{array}{l}-4.143 \\
(-0.54) \\
\end{array}$ & $\begin{array}{l}-3.433 \\
(-0.97) \\
\end{array}$ \\
\hline R-Squared & 0.1321 & 0.1542 & 0.1327 & 0.1543 & 0.1295 & 0.1542 & 0.1304 & 0.1543 \\
\hline Observations & 93104 & 93104 & 93104 & 93104 & 93546 & 93546 & 93546 & 93546 \\
\hline
\end{tabular}


Table 8: Immigrant Employment Status and Concerns over Immigration

\begin{tabular}{|c|c|c|}
\hline \multirow[b]{2}{*}{ Variables } & (1) & $(2)$ \\
\hline & EC & $\mathrm{CC}$ \\
\hline \multirow[t]{2}{*}{ Immigrant Share (in \%) } & $0.0782^{* *}$ & $0.0591^{* * *}$ \\
\hline & $(2.86)$ & $(3.16)$ \\
\hline \multirow[t]{2}{*}{ Owner Immigrants (in \%) } & 0.0182 & $0.267^{*}$ \\
\hline & $(0.11)$ & $(1.98)$ \\
\hline \multirow[t]{2}{*}{ Self-employed Immigrants (in \%) } & $0.0841^{*}$ & 0.00973 \\
\hline & $(1.99)$ & $(0.23)$ \\
\hline \multirow[t]{2}{*}{ Unemployed Immigrants (in \%) } & 0.0321 & $-0.0567^{*}$ \\
\hline & $(0.70)$ & $(-1.97)$ \\
\hline \multirow[t]{2}{*}{ Student Immigrants (in \%) } & $0.0984^{* *}$ & 0.0612 \\
\hline & $(2.39)$ & $(1.50)$ \\
\hline Individual Controls & YES & YES \\
\hline Country Controls & YES & YES \\
\hline Year Controls & YES & YES \\
\hline \multirow[t]{2}{*}{ Constant } & $-2.819^{* * *}$ & $-1.300^{* * *}$ \\
\hline & $(-4.63)$ & $(-3.53)$ \\
\hline R-Squared & 0.1331 & 0.1475 \\
\hline Observations & 70371 & 70371 \\
\hline \multicolumn{3}{|c|}{$\begin{array}{l}\text { Note: The independent variables used above represent share of total } \\
\text { population which denotes immigrants with employment relationship as } \\
\text { employee, owner, self-employed, and students. The share of unemployed } \\
\text { immigrants represent all the individuals who are foreign born and have } \\
\text { reported to be unemployed during last three months. t statistics in } \\
\text { parentheses: }{ }^{*} p<0.10, * * p<0.05, * * * p<0.01 \text {. }\end{array}$} \\
\hline
\end{tabular}

Table 9: Immigrant Skills and Concerns over Immigration

\begin{tabular}{|c|c|c|c|c|c|c|}
\hline Variables & $\begin{array}{c}\text { Full sample } \\
(1) \\
\text { EC }\end{array}$ & $\begin{array}{c}\text { Full sample } \\
(2) \\
\text { CC }\end{array}$ & $\begin{array}{c}\text { Low-skilled } \\
(3) \\
\text { EC }\end{array}$ & $\begin{array}{c}\text { Low-skilled } \\
(4) \\
\text { CC }\end{array}$ & $\begin{array}{c}\text { High-skilled } \\
(5) \\
\text { EC }\end{array}$ & $\begin{array}{c}\text { High-skilled } \\
(6) \\
\text { CC }\end{array}$ \\
\hline High-skilled Immigrant Share & $\begin{array}{c}0.154^{* * *} \\
(5.78)\end{array}$ & $\begin{array}{c}0.0594^{* * *} \\
(4.14)\end{array}$ & $\begin{array}{c}0.164^{* * *} \\
(5.13)\end{array}$ & $\begin{array}{c}0.0720^{* * *} \\
(5.02)\end{array}$ & $\begin{array}{c}0.121^{* * *} \\
(5.72)\end{array}$ & $\begin{array}{l}0.0210 \\
(0.79)\end{array}$ \\
\hline Low-skilled Immigrant Share & $\begin{array}{c}0.0598^{* *} \\
(2.29)\end{array}$ & $\begin{array}{c}0.0235 \\
(1.69)\end{array}$ & $\begin{array}{c}0.0731^{* *} \\
(2.60)\end{array}$ & $\begin{array}{c}0.0325^{* *} \\
(2.20)\end{array}$ & $\begin{array}{l}0.0266 \\
(1.63)\end{array}$ & $\begin{array}{c}-0.0000473 \\
(-0.00)\end{array}$ \\
\hline Individual Controls & YES & YES & YES & YES & YES & YES \\
\hline Country Controls & YES & YES & YES & YES & YES & YES \\
\hline Year Controls & YES & YES & YES & YES & YES & YES \\
\hline Constant & $\begin{array}{c}0.937^{* * * *} \\
(8.39)\end{array}$ & $\begin{array}{c}0.865^{* * * *} \\
(7.23)\end{array}$ & $\begin{array}{c}-2.598^{* * *} \\
(-2.85) \\
\end{array}$ & $\begin{array}{r}-0.796^{*} \\
(-1.92) \\
\end{array}$ & $\begin{array}{l}-0.891 \\
(-1.70) \\
\end{array}$ & $\begin{array}{l}0.237 \\
(0.56) \\
\end{array}$ \\
\hline R-Squared & 0.1326 & 0.1554 & 0.0874 & 0.1162 & 0.0950 & 0.1004 \\
\hline Observations & 92262 & 92262 & 63866 & 63866 & 28396 & 28396 \\
\hline
\end{tabular}


Table 10: Macro Cultural channels that shape Concerns

\begin{tabular}{lcccc}
\hline \hline \multirow{2}{*}{ Variables } & $\mathbf{( 1 )}$ & $\mathbf{( 2 )}$ & $\mathbf{( 3 )}$ & $\mathbf{( 4 )}$ \\
\hline Immigrant Share (MS) & $\mathbf{E C}$ & $\mathbf{C C}$ & $\mathbf{E C}$ & $\mathbf{C C}$ \\
& $0.0932^{* * *}$ & $0.0320^{* * *}$ & $0.196^{* * *}$ & $0.0533^{* * *}$ \\
MS*Religious Diversity 1970 & $(6.04)$ & $(3.95)$ & $(12.27)$ & $(5.84)$ \\
& $-0.147^{* * *}$ & -0.0169 & & \\
MS*Individualism & $(-3.49)$ & $(-0.63)$ & & \\
& & & $-0.00207^{* * *}$ & -0.000416 \\
Individual Controls & & & $(-4.16)$ & $(-1.52)$ \\
Country Controls & YES & YES & YES & YES \\
Year Controls & YES & YES & YES & YES \\
Constant & YES & YES & YES & YES \\
& $-1.456^{* *}$ & -0.358 & $-1.884^{* * *}$ & -0.369 \\
\hline R-Squared & $(-2.48)$ & $(-0.84)$ & $(-3.20)$ & $(-1.04)$ \\
Observations & 0.1303 & 0.1542 & 0.1303 & 0.1544 \\
\hline \hline
\end{tabular}

cerns towards immigration. The first two columns of the table analyze the religious channel in the form of historical presence of religious diversity in the country of the respondent. Columns (3), and (4) analyze another cultural channel: Individualism - the individualistic or collectivistic values present in the culture of the respondent's country.

Table 11: Immigrant Religious Identity and Concerns over Immigration

\begin{tabular}{lcccc}
\hline \hline & $(\mathbf{1})$ & $\mathbf{( 2 )}$ & $\mathbf{( 3 )}$ & $\mathbf{( 4 )}$ \\
Variables & $\mathbf{E C}$ & $\mathbf{C C}$ & $\mathbf{E C}$ & $\mathbf{C C}$ \\
\hline Immigrant Share & $0.0858^{*}$ & 0.0201 & $0.104^{* * *}$ & $0.0246^{* * *}$ \\
& $(2.03)$ & $(0.80)$ & $(3.76)$ & $(2.89)$ \\
Islamic Immigrants (in \%) & -0.0253 & 0.0360 & -0.0465 & 0.0282 \\
& $(-0.88)$ & $(1.37)$ & $(-1.57)$ & $(1.14)$ \\
Christian Immigrants (in \%) & 0.0275 & 0.00161 & & \\
& $(0.60)$ & $(0.04)$ & & \\
Immigrants from Other Religions (in \%) & -0.0459 & -0.0882 & & \\
& $(-0.71)$ & $(-1.35)$ & & \\
Individual Controls & YES & YES & YES & YES \\
Country Controls & YES & YES & YES & YES \\
Year Controls & YES & YES & YES & YES \\
Constant & $1.337^{* * *}$ & $1.591^{* * *}$ & $-2.877^{* * *}$ & -0.262 \\
& $(6.61)$ & $(9.91)$ & $(-3.06)$ & $(-0.84)$ \\
\hline R-Squared & 0.1309 & 0.1493 & 0.1309 & 0.1489 \\
Observations & 77076 & 77076 & 79728 & 79728 \\
\hline \hline Note: The listed independent variables represent share of immigrants in total population of the country \\
(MS), then immigrant share reported to the religions: Christianity, islam, and other religions (of Jewish, \\
Eastern religions, and Other non-Christian religions faiths). The omitted religion share of population is of \\
non-religious immigrants. t statistics in parentheses: * p $<0.10, * *$ p $<0.05, * * *$ p $<0.01$. &
\end{tabular}


Table 12: List of Right-Wing Parties

\begin{tabular}{lll}
\hline \hline Countries & References & Parties \\
\hline Austria & Mudde (2013) & Austrian Freedom Party (FPO) and Bundnis Zukunft Osterreich (BZO) \\
Belgium & Mudde (2013) & Vlaams Blok/Vlaams Belang (VB) and Front National (FN) \\
Bulgaria & Mudde(2012) & National Union Attack (NSA) \\
Switzerland & Ivarsflaten (2006) and Mudde (2013) & $\begin{array}{l}\text { Swiss People's Party (SVP), Swiss Nationalist Party (PNOS), } \\
\text { and Swiss Democrats (SD) }\end{array}$ \\
Croatia & Mudde (2012) & Croatian Party of Rights (HSP) \\
Denmark & Ivarsflaten (2006) & Danish People's Party (DF) and Danish Progress Party (FP) \\
Germany & Ivarsflaten (2006) & National Democratic Party of Germany(NPD) and The Republicans (REP) \\
France & Rydgren (2008) & Front National(FN), National Republican Movement (MNR), \\
& & and Movement for France(MPF) \\
Finland & Ivarsflaten (2006) & Finns Party (PS) and Finnish People's Blue-whites (SKS) \\
Greece & Ivarsflaten (2006) & $\begin{array}{l}\text { Popular Association - Golden Dawn (Golden Dawn) } \\
\text { and Popular Orthodox Party (LAOS) }\end{array}$ \\
Hungary & Mudde(2012) & Hungarian Justice and Life Party (MIEP), \\
& & and Movement for a Better Hungary (Jobbic) \\
Italy & Ivarsflaten (2006) & Social Movement - Tricolour Flame (MS-FT), and Lega Nord (LN) \\
Netherlands & Rydgren (2008)and Mudde (2013) & Pim Fortuyn List (LPF) and Party for Freedom (PVV) \\
Norway & Rydgren (2008) & Progress Party (FRP) \\
Portugal & Mudde(2012) & National Renovator Party (PNR) \\
Sweden & Ivarsflaten (2006) & Swedish Democrats (SD) \\
United Kingdom & Ivarsflaten (2006) & United Kingdom Independence Party (UKIP), \\
& & and British National Party (BNP) \\
\hline \hline
\end{tabular}

